\title{
Brain-drain warning over UK lab facilities
}

[LONDON] Britain's government minister responsible for universities warned last week that unless research facilities are improved, an increasing number of Britain's brightest science graduates will seek research positions in the United States.

The warning came from Baroness Blackstone, who, before her appointment last year as a minister in the new Labour government's Department for Education and Employment, was master of the University of London's Birkbeck College.

It coincides with a series of meetings between the Treasury and other departments about the government's future strategy for science funding that are being carried out as part of a comprehensive spending review.

Giving evidence to the House of Commons Select Committee on Science and Technology, Blackstone said that, in her former position, she had frequently been "ashamed" of the conditions in which researchers in many universities work.

"We have to do something," she said. Otherwise, the long-term consequences for Britain would be fewer highly qualified people working at the cutting edge of research. "That would mean we would lose out in terms of exports and general prosperity."

It could also mean wasting "an enormous amount of potential" among young scientists keen to do high-level research. "People who want to do research degrees will go to the United States, not because there is more research money, but because the research facilities are vastly superior to what we can provide. There is already a vast gap, and it is

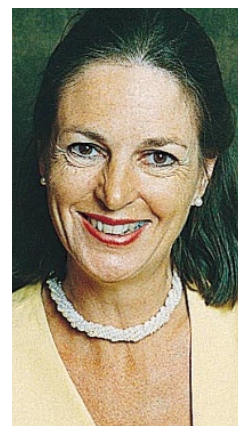

Blackstone: admits she was 'ashamed'. very important that that gap does not get any bigger."

Blackstone also spoke strongly in favour of the dual-support system, in which financial responsibility for university research is shared between the universities themselves (out of grants received from the government) and the research council.

"If we were to transfer [all funds for research] to the research councils, we would deny universities the opportunity to support the many young scientists who may not find it particularly easy to get substantial grants out of research councils," she said. "Also, there are many indirect costs of research which it is very difficult to be precise about, and for which the dual-support system provides an important cushion.'

The future of this system, and in particular of government funding for infrastructure costs incurred by research funded through the research councils, is high on the spending review's agenda. It was identified as an area in need of urgent attention by the National Commission on Higher Education, chaired by Lord (formerly Sir Ron) Dearing, in its report last summer.

Treasury officials on the review have recently heard an outline of the view of the Office of Science and Technology presented by Sir John Cadogan, director-general of the

\section{German chemist sues over fraud allegation}

[MUNICH] Guido Zadel, a former chemist at the University of Bonn, who has been accused of committing scientific fraud four years ago, is suing the Land (state) of Nordrhein-Westfalen for DM437,000 (US\$242,000) compensation.

Zadel's lawyer claims that, as a direct result of the accusations, he has been unable to find a suitable post, and that the sum represents the amount a chemist of his age and qualifications could expect to earn in industry over four years.

Zadel is also seeking DM200,000 in damages from a former co-worker who has said that he saw Zadel manipulating experiments. Zadel is challenging a decision by the university to withdraw his doctorate.

Zadel had claimed to have discovered that a static magnetic field could, even without the use of polarized light, induce 'chiral synthesis' - the stereo-selective synthesis of optically active organic substances - a discovery that would have had enormous significance for the pharmaceutical industry. Doubts soon arose about his claims, however, as no other research group was able to reproduce them (see Nature 382, 104; 1996). Zadel admits that his methods were "far from being mature". But he rejects charges that some failed experiments had not been properly recorded, and denies scientific misconduct.

Part of his defence is that, although his own paper was withdrawn soon after publication, two subsequent papers by other researchers appear to provide some theoretical support for his ideas. Both conclude that chiral synthesis in a magnetic field is in principle possible.

But researchers at the University of Bonn's Institute of Organic Chemistry have no plans for further work on the topic. "The common opinion is that chiral synthesis in a static magnetic field is impossible in practice," says Karl-Werner Glombitza, dean of natural sciences.

Quirin Schiermeier research councils, as well as individual presentations from the heads of the six research councils. A summary of these views is due to be delivered to a ministerial-level Treasury panel this week.

It is widely thought that the outcome of the review, due to be published in the summer, will be to peg future increases in science spending close to the expected level of inflation. (Budget figures for 1998-99, released last week, show an increase of only 0.6 per cent, in line with the plans of the former Conservative government.)

But the key questions are likely to be who should control how this money is spent that is, what should be the balance between the universities and the research councils and what external sources of funding can be secured for the science base, particularly from the private sector.

At last week's select committee hearing, Blackstone endorsed the universities' widespread opposition to the extra overhead costs of research council projects being met out of a further transfer of funds from Britain's four higher-education funding councils to the research councils. Such a move would reduce the universities' control over how these funds are spent.

Her warnings were echoed by John Battle, the minister for science, energy and technology. In his evidence to the committee, Battle pointed out that such a move would reduce the flexibility of university vice-chancellors to target funding on promising new fields.

But Battle also warned of the consequences of asking the research councils to increase their overhead costs - Dearing has suggested these should rise from 45 to 60 per cent of the direct costs - without additional funding from the Treasury.

Although the Royal Society appears to have been relatively sanguine about accommodating such a shift by cutting funding for lower-priority research projects, Battle warned that the effects would be devastating. "We would have to impose a moratorium on all new grants and studentships," he said.

On a more positive note, Battle told the committee about the success of a two-yearold scheme to encourage joint private/public funding of university research equipment. Figures released two weeks ago showed that $\mathfrak{E 3 5}$ million (US\$58 million) provided last year by the funding and research councils towards this Joint Research Equipment Initiative - about $\mathfrak{E} 13$ million more than originally planned - was matched by external contributions of just under $\mathfrak{E} 45$ million.

Applications for support from the scheme, which the government had initially planned as a one-off event but which is now to be organized annually, were heavily oversubscribed. 